\title{
The Importance of Anti-Corruption in Education Field
}

\author{
Alfalachu Indiantoro \\ Faculty of Law, Universitas Muhammadiyyah Ponorogo, Indonesia \\ \{indiantoro.a@gmail.com
}

\begin{abstract}
Every crime has a negative effect especially corruption. The efforts to eradicate corruption in Indonesia, including the establishment of the Corruption Eradication Commission (KPK) in 2002 that has revealed many corruption problems, has not helped to improve Indonesia's ranking in International Transparency. Another way in dealing the corruption is by applying formal anticorruption education in the education side, which has several advantages such as low-budget needs and systematic and sustainable programs. Anti-corruption education is formally an important education that can no longer be postponed. The importance of characteristics growth, in this case, the values of anticorruption education efforts, are the synergies between the utilization of information and knowledge.
\end{abstract}

Keywords: Understanding, Anti-Corruption, Education Field

\section{Introduction}

This country, it is not wrong if there is a joke that says, "Indonesia Today does not have an original product that reflects as a nation's wealth, except corruption." Large companies that stand majestically do not belong to the community or the elite of large Indonesian investors, but the property of foreign investors.In various literature submitted, corruption is a disease that is favored by various nations in the world, including Indonesia; it comes from Latin "corruption" or "corruptus"[1]. Corruption comes from "corumperre," the older Latin word. From the Latin that goes down to many European languages like English that is corruption, corrupt; France that is corruption and Dutch is corruptive, then from Dutch language this word down to Indonesian language that is "korupsi", which then become so familiar disease which some people hate and hostile, but some others are very fond of[2].

Corruption is the most crucial problem facing the country and the nation of Indonesia today[3]. The criminal acts of corruption that occurred stretch from petty corruption such as giving of lubricant money when dealing in the urban village to big corruption such as misuse of state fund worth trillions of rupiah. This incident increasingly clarifies the notion that corruption has become a culture in the life of Indonesian society. Various efforts have been made to combat corruption in the country of Indonesia, among others by establishing State bodies that are given extraordinary powers such as the Corruption Eradication Commission (KPK). Since it's established in 2002 until now, KPK has taken action against various corruption issues but Indonesia's Corruption Perception Index (IPK) as reported by International Transparency (TI) still remains low.

Many international publications explain the culture of corruption in Indonesia. Even in 2010, Indonesia is ranked among the most corrupt countries in the Asia Pacific, and in 2011 
Indonesia's corruption perception index (GPA) is 3.0 ranking 100 out of 183 countries in the world (International Transparency, 2011). Responding to the phenomenon, it is needed a holistic effort in eradicating corruption both in terms of law enforcement officers[4], policymakers to the formal education in the world of education/ school[5].

Some countries have implemented their understandings and anti-corruption education in the academic world and have shown significant results. Hong Kong has been conducting anticorruption education since 1974 and shows remarkable results.If Hong Kong is a corrupt country and its corruption is described as "from the womb to tomb" in 1974, now Hong Kong is one of the countries in Asia with a very high grade of 8.3 and the 15 th cleanest country in 158 countries in the world[6].

This success is the effect of cooperation programs of corruption eradication efforts from all aspects including anti-corruption education conducted in the world of education formally[7]. When compared to other anti-corruption strategies, the implementation of anti-corruption education in the formal education will give some benefit to the state both pragmatically, theoretically and philosophically.

First, formal educational institutions are stable institutions. Second, it does not increase the government's budget. Third, it can be implemented systematically and continuously, and the nation's investment is in the long term. The importance of anti-corruption education has become part of national education as defined in the regulation of the Minister of National Education (Permendiknas) No.22 and No. 23 Th.2006 on standards of contents and Standards of graduate competence for elementary and secondary education units.

\section{Discussion}

Anti-corruption education is an educational program on corruption that aims to build and raise citizens' awareness of the problems and consequences of corrupt acts. The main targets of anti-corruption education are to explain the phenomenon of corruption that includes the criteria, causes, and consequences, increases the intolerance of corruption, shows possible attempts to combat corruption and contributes to predetermined standards such as realizing values, character and capacity to prevent corruption young generation. Besides that, the students are also guided and directed to analyze the standard values that contribute to the occurrence of corruption, as well as the values that reject or disagree with the act of corruption. Therefore anti-corruption education is the planting and strengthening of the basic values that are expected to shape the attitude of anti-corruption in the learners.

The Lithuanian education department that has implemented anti-corruption education in the country since 2005 says that the main task of anti-corruption education in schools is to provide students with explanations how students can distinguish between crimes of corruption and other forms of crime, providing a logical and rational argument of why corruption is perceived as a crime, and show ways that can be taken in reducing the occurrence of acts of corruption.

Based on [8] in general, the purpose of anti-corruption education is, first: the formation of knowledge and understanding of the forms of corruption and aspects of its aspects; second: changing perceptions and attitudes toward corruption, and third: the formation of new skills and skills aimed at fighting corruption. With these three objectives, it can be seen that anticorruption education, although it has the main target as a value education still includes the three domains of education as proposed by Bloom is the student's development of the cognitive, affective and psychomotor aspects. 
Corruption Eradication Commission (KPK) formulated that there are nine basic values that need to be instilled and reinforced by the implementation of anti-corruption education in the world of education, namely the value of honesty, courage, simple living, fair, responsibility, hard work, frugal, disciplined and independent. These values have existed in society since ancient times, and are contained clearly in the basic philosophy of the Pancasila state, but are beginning to be eroded by the consumptive culture brought by the modernization and globalization. In accordance with the objectives to be achieved, the implementation of anticorruption education in the world of education needs to pay attention to several things related:

\subsection{An understanding of what corruption is}

Right understanding about the meaning of corruption in the world of education whether it is school or college, need to get various information about what is the act of corruption so that students or students understand very well the difference between acts of corruption, and able to distinguish between criminal acts of corruption with other crimes. Therefore, the discussion of the criteria, causes, and effects of corruption is a fundamental subject that must be submitted in the world of education. Besides, students or students also have a clear argument about why the act of corruption is considered as a wrong act and should be avoided.

The analysis of the effects of corruption on various aspects of human life, especiallyon the aspect of morality, will provide insight into the education world about the understanding of wider corruption. In the end, various alternatives can be taken to avoid corruption can be an inspiration for the education world about many ways that can be done in combating corruption. This is the basic modal in planting or forming the attitude and character of anti-corruption society. From the understanding is expected learners can assess the existence of corrupt behavior in society or surrounding institutions. Therefore the provision of information about corruption is not to provide as much information as possible to the students, but the information is necessary so that students can make certain considerations in judgment. In other words, his knowledge about anti-corruption education learners can assess whether an act that includes corruption or not, and whether the act is categorized good or bad. With these considerations, further learners are able to determine the behavior that will do.

\subsection{Efforts in the development of attitudes}

As education of values and character, anti-corruption education gives great attention to the development of the attitude aspects of learners. Human attitude is a major predictor of everyday behavior[9]. Attitude is the disposition of judgment given to an object based on knowledge, affective reactions, willingness and behavior before the object[10]. From the elements above are interconnected and exchange places such as affective reactions overshadowed by the usual behavior. Therefore, a pro-corruption attitude is not a category,but it also contains something else. Changes to one element will also change the other. For example, eliminating intentions and behaviors may alter cognition, affective attitude, and reactions.

Therefore, when providing information about anti-corruption education, educators should strive to develop an attitude based on cognition. For that learners must have a cognition or knowledge that is true and well understood, so that knowledge can last long in the memory and can be used every time they will make consideration. In addition, intense involvement in activities containing anticorruption values will also develop an attitude appropriate to the value. 


\subsection{Efforts to change attitudes}

Changing attitudes that have been embedded before is a tough job, and sometimes frustrating. Moreover, if the attitude is contrary to the attitude desired by educators, for example, cheating in the exam is common among learners. Other examples pay the police for violating traffic rules, and so on.Anti-corruption education requires that these attitudes need to be avoided to conform to the basic values of anti-corruption education. Therefore, it is necessary to adopt patterns and strategies of change of attitudes that can be used from various sources, such as to establish perceptions about corruption that are contrary to the perceptions that learners can have by presenting information unexpectedly through the game. Another strategy for changing attitudes is based on the fact that knowledge and attitudes are stored in different places or memories, so it takes time to achieve both, meaning that the process of knowledge changes into attitudes that require considerable time. Therefore, if there is a prostance on corruption should not be attacked directly or overcome persuasively. In a long time, that attitude will change itself if information that corrupts corruption is presented in a meaningful way and lure learners to think critically about the problem of corruption. Because this is a reaction called the postponement effect, which initially information will not be believed but then correct knowledge will overcome affective reactions.

\subsection{Improvements in character development}

Anti-corruption education is not a set of rules that are created by a person and must be followed by others. As with other crimes, corruption is an option that can be done or avoided. Therefore education is conditioned for the behavior of learners by the demands of society. For the behavior to be the character of the learner, then some steps can be done in anti-corruption education, such as Train to determine the choice of behavior. For that, the student must be informed about the rights, obligations, and consequences of the actions he/she performs.

Provide opportunities for learners to develop a broad understanding by creating a flexible situation where learners can cooperate, share, and obtain the necessary guidance from educators. Therefore, activities in analyzing cases, discussions, role plays or student interviews are situations that will develop an anticorruption character in self and focus on the findings of facts.

Engaging in various social activities in the educational world and the environment, it intends to instill a sense of responsibility and respect for others, to train them to share the social responsibility in which they live. It does not mean that other characters are not important but by expressing a sense of responsibility and respect in others will reduce the selfishness and selfishness that many corruptors have.

Implications for learning referring to the aims and targets of anti-corruption education above, anti-corruption learning should be designed in a moderate and non-indoctrinate way.The learning experienced by students is learning that gives the meaning that they are parties or citizens who participate in thinking about the future of this nation and the country forward, especially in the effort to eradicate corruption. Only by placing learners in this position anticorruption, education will have important meaning. Otherwise, they will tend to assume that anticorruption education is merely a political matter because they are not corrupt people and will not necessarily corrupt.Given the role of cognition in the formation of human attitudes and behavior, the establishment of appropriate knowledge about corruption is the first step in anti-corruption education.For that, learning must pay attention to the process of how 
knowledge can be owned by students.Knowledge may be acquired through various sources, accumulated and stored in the form as they are received, but strong and deep knowledge derives from the individual's activeness in building the meaning of something along with his interaction with his physical environment and social environment. Therefore learning is an active process in building knowledge and meaning, and building knowledge will give way to building conceptual understanding which is an important factor in solving a problem.Thus, anticorruption learning should actively involve learners in building dignified knowledge. Active learning requires learning activities in which learners are given sufficient autonomy to control the direction of learning activities such as investigating and solving problems. In other words, anticorruption learning can use various ways or strategies, provided that the method or strategy involves students actively both physically and mentally.In other words, an active learning process puts students in a situation that makes them engage in activities that have been designed by educators for a particular purpose[11].

\subsection{Understanding the views of the Convention and morals}

Anti-corruption education is based on value education that is not so clearly differentiate between the two social regulations of convention and morality. The Convention is a norm based on a common agreement that exists in a society, so it is not mandatory for other communities because it is not universal. In a moral perspective, good behavior is said to be good because it is universally accepted and the duty of all people. Furthermore, from a moral perspective,action is judged as good or bad by looking at the consequences, whether the action is painful to the person, or bringing harm, or violating the sense of justice for all.

Furthermore, the quality of action may be determined by one's intentions.An action is unacceptable if the intent or intent of the offender is bad, although in a situation the result is not bad or bad, and otherwise can be considered if the intent is good even if the result fails. In fact, the life of morality and convention are intertwined. Common moral principles fall into norms such as forbidden to steal, forbid lying, to be fair to others. In other words, morality and convention are on different concepts and also have different logic.

Anti-corruption education should pay attention to the difference between convention and morality. From any conventional view can be done as long as it is not forbidden, but the moral perspective of an act is seen whether it is in the norm or not. The moral view is more sensitive to seeing the effect it has on a person while the convention views more on the violation, consistency, and expectation of the authority owner. Violations of the principle of morality lead to a stronger affective reaction. Human behavior in response to moral or convention violations is also different.

If they break their moral principles, they apologize or try to find justification or reason for their actions. Meanwhile, if they violate the convention, they will criticize the source of the norm. Therefore man knows instinctively which morality and which is the confession. Based on Kohlberg[12] stages of moral development of learners and acceptance of the convention, then anti-corruption education, should be implemented by the readiness of moral development owned by learners.

One of the most important things is that corruption is judged evil from a moral and conventional perspective. Moreover, Aspin[13] said that regardless of the value to be included in education, then moral education is the main thing because it is part of the obligation to prepare young people to enter a world that desires better behavior than ever.Therefore education that strengthens the morality of learners must be handled by educational institutions seriously. 


\section{Conclusion}

Understanding anti-corruption is an education that can no longer be postponedinformal education. If implemented properly, in the long term anticorruption education can contribute to the prevention of corruption, as is the experience of other countries.By having anticorruption education, it is expected that the young generation will have anti-corruption character as well as to free Indonesia as a high ranking country in terms of corruption.Characteristics of anti-corruption education are the need for a proper synergy between the use of information and knowledge possessed with the ability to make moral judgments.Anti-corruption learning cannot be carried out conventionally but must be prepared with the design in such a way that aspects of cognition, affection,and future generations can be developed in a maximum and sustainable.

\section{References}

[1] A. Ikhwan, Politik uang dalam pemilihan umum (studi pada pemilihan umum anggota dewan perwakilan rakyat daerah kabupaten tulungagung tahun 2014), Penelitian. Tulungagung: KPUD Tulungagung, 2015.

[2] Hermawan, Korupsi Tanpa Tanding, Episode Keberlanjutan Keterpurukan Indonesia. Jakarta: LPKI pembebasan Indonesia, 2010.

[3] V. I. Wafda, "Korupsi Dalam Dimensi Kekuasaan," LAW PRO JUSTITIA, vol. 1, no. 2, 2016.

[4] U. Agianto, "Law Enforcement in Indonesia: Exploration of the Concept of Justice in Islamic Dimension with Pancasila Ideology," Al-Hayat J. Islam. Educ., vol. 2, no. 2, pp. 246-254, 2018.

[5] G. J. Aditjondro, "Bukan Persoalan Telur dan Ayam. Membangun suatu kerangka Analisis yang lebih Holistik bagi gerakan Anti Korupsi di Indonesia," J. Wacana, vol. 14, 2002.

[6] K. Harahap, "Pemberantasan Korupsi pada masa Reformasi," J. Hist. Stud., vol. X, no. Juni, 2009.

[7] T. K. Man-wai, "Formulating an Effective Anti-corruption Strategy: The Experience of Hongkong ICAC,” Resour. Mater. Ser., vol. 69, pp. 196-201, 2002.

[8] B. Dharma, "Korupsi dan Budaya," 2004. .

[9] D. Zuchdi, "Pembentukan Sikap," J. cakrawala Pendidik., vol. 3, no. 3, 1995.

[10] M. Fishbean and A. Icek, Belief, Attitude, Intention and Behafior: An Introduction to Theory and Research.Addison. USA: Wesley Publishing, 1973.

[11] S. A. Ghofur, "Merancang Kurikulum Pendidikan Antikorupsi," J. Pendidik. Islam, vol. 1, no. 1, 2009.

[12] R. E. Slavin, Educational Psychology: Theory and Practice. Boston: Allyn and Bacon, 1994.

[13] D. N. Aspin and J. D. Chapman, Values Education and Lifelong Learning. Netherland: Springer, 2007. 